\title{
Identifying and categorizing stakeholders for protected area expansion around a national park in Namibia
}

\author{
Lelani M. Mannetti $^{1}$, Thomas Göttert ${ }^{2}$ Ulrich Zeller $^{2}$ and Karen J. Esler ${ }^{3}$
}

\begin{abstract}
Protected areas and adjacent landscapes are increasingly being viewed as integrated. A more general awareness is emerging of the relevance of collectively managed landscapes for conservation and human well-being. In Namibia, areas dedicated to conservation are increasing because of the proliferation of conservancies and game reserves. Management toward integrated conservation in these landscapes involves land use practices variably dedicated to wildlife management and the inclusion of land owners and resource users in the decision-making process. We use stakeholder analysis to identify participants integral to an expanded protected area network around the Etosha National Park in Namibia. We identified and categorized important stakeholder groups, and quantitatively and qualitatively assessed their relative importance to the protected area decision-making process. Twelve stakeholder groups were identified, and categorized according to proximity to the national park, land tenure, and land use type. Primary stakeholders, those who both affect and are affected by decision making, comprised livestock farmers, communal conservancy members, resettlement farmers, and tourism/hunting enterprises. For each group the cumulative values of position (level of support for, or opposition to the concept), interest (perceived disadvantages and advantages thereof), and power (resources stakeholders can mobilize to express their position) were calculated. These attributes provide an indication of stakeholder salience, i.e., how likely stakeholders are to affect or be affected by an integrated conservation landscape. We find that livestock farmers, although interested in the concept, mostly oppose protected area expansion. The conflict in opinion is linked to the benefits derived from being part of the conservation landscape and the losses endured due to the porous park fence, including human-wildlife conflict and regulations involving a veterinary cordon fence. A consideration of stakeholder salience, taking into account the different perceptions surrounding the benefits of living adjacent to a protected area, can potentially lead to the better implementation of integrated conservation areas.
\end{abstract}

Key Words: conservation landscapes; primary stakeholders; salience; stakeholder analysis

\section{INTRODUCTION}

Protected areas are important refuges for biodiversity (Myers et al. 2000, Pimm et al. 2001) and are crucial for the conservation of species threatened by land use change and habitat loss (Chape et al. 2005, Gaston et al. 2008, Joppa et al. 2008, Palomo et al. 2013, 2014). In some cases, protected areas are becoming isolated in the landscape because of land use change and intensification (DeFries et al. 2005, Foley 2005, DeFries and Rosenzweig 2010), while other protected areas have been developed according to integrative approaches that address biodiversity conservation alongside human livelihood concerns (MA 2005, Bengtsson et al. 2003, Naughton-Treves et al. 2005, Kareiva and Marvier 2012, Zeller et al. 2017). Increasingly, more inclusive planning processes and coordination between conserved areas and surrounding communities are being called for (Reed 2008, Heller and Zavaleta 2009).

The successful integration of protected areas and surrounding landscapes depends on interactions between various stakeholders, including practitioners, policy makers, and resident communities (Kothari 2008, Lockwood et al. 2012). Protected areas are affected by and can have an effect on such stakeholders, either directly or indirectly, through their use of resources and land use decision making (Lockwood 2010). For effective stakeholder engagement, a strategic view of the social and institutional setting, which includes the issues stakeholders consider most salient and imperative to their well-being, is required (Mannetti et al. 2017).
A failure to do so can lead to a lack of support from local communities and practitioners, making the aims of integrated conservation approaches futile. We present a case study of stakeholder identification and categorization regarding resident community inclusion in an expanded protected area around the Etosha National Park (ENP) in Namibia. By taking into account the perspectives and interests of those being integrated into the conservation landscape prior to protected area expansion, our approach attempts to reduce the risks of land use conflicts typically associated with people living adjacent to protected areas (Andrade and Rhodes 2012).

In southern Africa several participatory approaches to environmental management have emerged, focusing on the collective management of nature by conservation authorities and neighboring communities (Perrotton et al. 2017). Recognized as integrated conservation or community-based conservation, these inclusive approaches emerged as a result of the failures of topdown bureaucratic approaches to wildlife conservation (Fabricius et al. 2004). Initially, southern African community conservation initiatives led to a wide range of livelihood and conservation impacts, in some instances resulting in the large-scale expansion of wildlife-based land uses and a considerable growth in locally captured benefits from natural resources (Roe et al. 2009). There have been failures, however, relating mainly to human encroachment on ecosystems, particularly poaching and deforestation in protected areas, threatening not only the viability

\footnotetext{
${ }^{1}$ Urban Studies Institute, Andrew Young School of Policy Studies, Georgia State University, Atlanta, GA, USA, ${ }^{2}$ Systematic Zoology Division, Albrecht Daniel Thaer-Institute of Agricultural and Horticultural Sciences, Faculty of Life Sciences, Humboldt-Universität zu Berlin, Berlin, Germany, ${ }^{3}$ Department of Conservation Ecology and Entomology and Centre for Invasion Biology, Stellenbosch University, South Africa
} 
of wildlife populations (Watson et al. 2014), but also the livelihoods of resident communities (see Siamudaala et al. 2009, Namukonde and Kachali 2015). Failures are tied to the poor support for conservation initiatives by local residents and are attributable to a number of factors, mostly centered on the exclusion of communities in the protected area decision-making process (Roe et al. 2009), a lack of benefits flowing to people living with wildlife (Lindsey et al. 2014), increased incidences of humanwildlife conflict (Guerbois et al. 2012, Chitakira et al. 2015), as well as conflicting values and perspectives regarding ecosystem benefits (de Groot et al. 2010, Bennett et al. 2015).

We argue that where multiple users of the same resource, namely the natural environment, have divergent values or conflicting interests such as production, subsistence, or conservation, a need lies in first understanding their different perspectives. In a similar study, Rastogi et al. (2010) assessed the relationships, importance, and power of stakeholder groups to protected area management outside the Corbett National Park in India, highlighting the need to understand divergent opinions on the same issue to reduce conflict. Using prescribed attributes, Nastran (2014) determined stakeholder salience of individuals and groups involved in the implementation of the Kamniško-Savinjske Alps Regional Park in Slovenia and found that the salience of different stakeholder groups differ during the various project stages. Building on this approach to stakeholder analysis and protected area decision making, we identify and categorize stakeholders based on their perspectives and interests in being incorporated into a multifunctional conservation landscape, explicitly taking into account their self-perceived power and importance in the protected area decision-making process.

\section{Expanding the protected area network in Namibia}

Community-based conservation in Namibia is largely considered a success by local communities, development NGOs, and the government (Brown and Bird 2011). This is attributable to policy reforms that led to the devolution of rights over resources at a local level (Jones 2010), which in turn resulted in an increase in conservancies, i.e., large areas designated for the protection and conservation of natural resources, and a recovery of wildlife populations (Weaver and Petersen 2008). Biophysical and socioeconomic conditions have led to there being minimal opportunity costs of alternative land uses (Roe et al. 2009), while institutional structures allow for cooperation between the private sector and communal conservancies (Mannetti et al. 2017).

The protected area landscape is thus effectively expanding because of the proliferation of communal and freehold conservancies (Weaver and Skyer 2003, Weaver and Peterson 2008, NACSO 2014, 2015). Overall, the protected area network expanded by $28,983 \mathrm{~km}^{2}$ (9\%) between 2010 and 2013 (MET 2014), directly affecting roughly 195,000 people, or $13.9 \%$ of the population (NACSO 2016). Together with national parks and private game reserves, these conservancies ensure that, to some degree, roughly $40 \%$ of the country is dedicated to wildlife conservation (MET 2010). This expanded protected area network includes different land use types and policy sectors, thereby generating multiple interdependencies between various stakeholders. Stakeholders include the state, groups and entities from international donors and NGOs, to private and communal farmers, communities, traditional authorities, and hunting and tourism enterprises.

\section{Stakeholder involvement in protected area management}

Because it is not possible to include all stakeholders in the expansion of the protected area network surrounding ENP, we applied stakeholder analysis to our study (see Table 1 for an explanation of key terms used). Stakeholder analysis is a technique used to generate knowledge about participants and to better understand their interests and behaviors, ultimately assessing stakeholder value in decision making (Varvasovszky and Brugha 2000). Although rooted in political economics, the stakeholder analysis approach has increasingly been used to identify stakeholders that influence the decision-making process surrounding natural resources (Reed et al. 2009). Generally, stakeholder analysis is used to generate information on the relevant participants in an attempt to understand their actions, perceptions, agendas, and influence on decision-making processes (Brugha and Varvasovszky 2000). It also helps identify opportunities and threats to projects, finding compatibility between objectives and stakeholder aspirations (Chevalier and Buckles 1999) and to better understand the diverse range of potentially conflicting stakeholder viewpoints (Friedman and Miles 2004, 2006, Prell et al. 2007).

According to Freeman (1984), stakeholders are those who are affected by the choices and actions taken by decision makers and who have the power to influence those choices. Mitchell et al. (1997) suggest that individuals, groups, communities, organizations, societies, and the natural environment are all entities that qualify as being actual or potential stakeholders. The existence and nature of the stakes, i.e., shares or interest in a situation, is what generates disparity, because whatever is believed to constitute a stake is that which will inevitably dictate what counts (Mitchell et al. 1997). Therefore, defining who or what stakeholders are is linked to defining what makes a legitimate stake. Much of the literature makes implicit assumptions about the legitimacy of stakeholders (Friedman and Miles 2002) presuming that stakeholders are self-evident and self-construed. This makes it challenging to know which stakeholders should be involved in identifying relevant issues (Dougill et al. 2006) and to subsequently categorize stakeholders to better understand their interests and relationships.

It is necessary to identify who holds a stake and the nature of the stake held. In our study, the scenario under analysis is the incorporation of adjacent land users into the integrated protected area network around ENP. The country's long-term vision is to develop a system of integrated land and natural resource management, essentially transforming the current protected area patchwork into a protected area network, involving state-owned protected areas, game parks, private nature reserves, tourism concessions, freehold and communal conservancies (Brown et al. 2005). Our research places stakeholder involvement in the context of natural resource management and protected area decision making. The aims of this paper are (a) the identification of primary stakeholders related to an expanded protected area network, (b) the categorization of primary stakeholders according to their perceived interests in an integrated landscape, their degree of support for the concept, and their power to influence it, and (c) a calculation of stakeholder importance in protected area decision making. 


\section{METHODS}

\section{Study area}

The study was conducted along the southern and southwestern border of $\operatorname{ENP}\left(22,270 \mathrm{~km}^{2}\right)$ in the Kunene region of Namibia (Fig. 1a). The region has a semiarid to arid climate with less than $50 \mathrm{~mm}$ to approximately $350 \mathrm{~mm}$ of average annual rainfall (Mendelsohn et al. 2003). The mountainous topography leaves large areas of the landscape inaccessible, and combined with the aridity, this significantly hinders agriculture (Mendelsohn 2006). The region's economy is dominated by tourism and hunting enterprises, sedentary livestock production at low stocking rates, and seminomadic pastoralism (Mendelsohn 2006). The area supports a variety of arid savanna and desert-adapted mammalian species, including African elephant (Loxodonta africana) and black rhinoceros (Diceros bicornis; Schwabe et al. 2015). Predators include lion (Panthera leo), leopard (P. pardus), cheetah (Acinonyx jubatus), spotted hyena (Crocuta crocuta), and brown hyena (Hyaena brunnea; Lindsey et al. 2013, Trinkel et al. 2017).

Fig. 1. Map of the study area in northwestern Namibia, including the Etosha National Park (ENO), private, and communal farms (a). The veterinary cordon fence or "red line" (dashed line) divides adjacent rangelands in the study area from the ENP and is a double fence (b), consisting of a high gameproof fence (right) separated by a $10-\mathrm{m}$ passage from a stockproof fence on the side of the farms and communities (left).

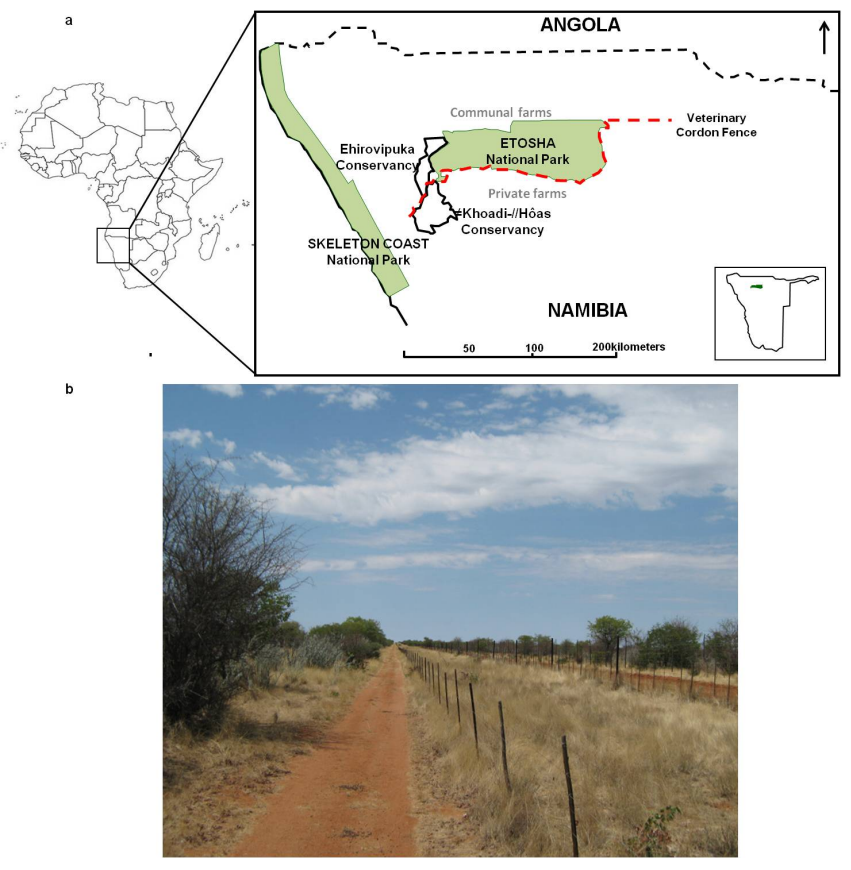

The ENP is surrounded by several land users, including private and communal livestock farmers, game reserve owners/managers, communal conservancy members, and "resettlement" farmers. On resettlement farms, communities reside on land procured by the state in an attempt to equitably distribute social, economic, and ecological benefits of land and natural resources to previously disadvantaged citizens. Here, land has been parceled into smaller units and distributed by traditional leaders to subsistence livestock farmers. To the west of ENP, two conservancies cover more than $5000 \mathrm{~km}^{2}$ and are home to approximately 5000 agropastoralists with access to benefits from wildlife (NACSO 2016). To the south of ENP, private land is variably dedicated to livestock production, wildlife production, and combination livestock and wildlife farms (Jokisch 2009). Private game reserve and livestock farmers own the properties on which they operate, while communal livestock farmers have limited rights to either communal conservancies or resettlement farms.

Apart from a boundary fence, ENP is also surrounded by a veterinary cordon fence, a control method for establishing disease-free zones in beef exporting countries (Scoones et al. 2010). It separates the conservancies in the west and private land in the south from ENP (Berry 1997). The fence is therefore a double fence, consisting of a high game-proof fence separated by a 10-m passage from a stock-proof fence on the side of the farms and communities (Fig. 1b).

\section{Sample selection and interview protocol}

A pilot study was conducted in February 2013 to identify relevant stakeholders in the study area and to design the interview schedule. During April to June 2013, primary data were collected using participant observation, key informant structured interviews, and semistructured interviews with representatives from each stakeholder group (Chambers 1997). Stakeholder interviews ( $\mathrm{n}=82$, varying from $60-90$ minutes in duration) were then conducted with landowners and managers, conservancy members, resettlement farmers, conservation professionals, and other experts in the area, and on individual farms along the southern border of ENP. Apart from two landowners who declined the interview, all private landowners/managers were interviewed. In the communal conservancies and resettlement farm, a representative sample of 12 households was interviewed in each community. See Appendix 1 for the study sample of individuals interviewed and the sample selection techniques used. Formal, closed-ended questions were used to guide the interview and maintain structure, while open-ended questions allowed interviewees to speak freely and discuss issues they deemed relevant to the study, encouraging the emergence of unexpected themes and issues (Creswell 2009). Our research observed the international ethics guidelines of informed prior consent, avoiding harm and providing benefit wherever possible.

\section{Data analysis}

Interview protocols were translated, transcribed, and analyzed, with codes and categories being derived according to the research questions. Using QSR-NVivo (version 10), codes were assigned to words, phrases, and sentences (Hutchison et al. 2010) that referred to stakeholders' perceived interests and how important stakeholders considered themselves to be in relation to the proposed protected area landscape (see Appendix 2 for a description of stakeholder identification and categorization). Stakeholders were further distinguished as primary or secondary, based on their stakes in the implementation of an expanded protected area system around ENP(Clarkson 1995; Table 1). The factors describing stakeholders' attributes were position (stakeholder level of support for, or opposition to, an expanded protected area network), interest (perceived disadvantages and advantages of being part of an integrated landscape, and power 
Table 1. Explanation of key terms used in the text.

\begin{tabular}{|c|c|}
\hline Term & Definition \\
\hline$\overline{\text { Stake }^{\dagger}}$ & $\begin{array}{l}\text { An interest in a situation, in this case the expansion, management, and development of the protected area network around } \\
\text { Etosha National Park (ENP). } \\
\text { Originates from geographical proximity, dependence for livelihood, economic interest, institutional mandate, historical } \\
\text { association, and various other capacities and concerns. }\end{array}$ \\
\hline Stakeholder ${ }^{\dagger}$ & $\begin{array}{l}\text { An individual, group, or organization who possesses a direct, significant, and specific stake in the expansion, management, } \\
\text { and development of the protected area network around ENP. }\end{array}$ \\
\hline Position & The stakeholder's level of support for, or opposition to, the stake. \\
\hline Interest & The stakeholder's perceived disadvantages and advantages of the stake. \\
\hline Power & The resources a stakeholder is able to mobilize in order to express their position. \\
\hline Salience & $\begin{array}{l}\text { The extent to which a stakeholder is able to prioritize their stakes or interests in other stakeholders' agendas. Refers to the } \\
\text { degree to which decision makers give priority to competing stakeholder claims. }\end{array}$ \\
\hline Active stakeholder ${ }^{*}$ & Those who affect (determine) a decision or action. \\
\hline Passive stakeholder ${ }^{\ddagger}$ & Those affected by the decision (whether positively or negatively). \\
\hline Stakeholder Analysis ${ }^{\dagger}$ & $\begin{array}{l}\text { A holistic approach or procedure for gaining an understanding of the current social-ecological system and assessing the } \\
\text { impact of changes to that system, by means of identifying key stakeholders and assessing their respective interests in the } \\
\text { system pertaining to an expanded protected area network around ENP. }\end{array}$ \\
\hline 1997) & irimble and Wellard (1997). \\
\hline
\end{tabular}

(the resources a stakeholder is able to mobilize in order to express their position).

These attributes were assessed using unipolar scales anchored at the ends, i.e., stakeholders were rated based on the presence or absence of an attribute, namely position, interest, or power, with the midpoint indicating indifference/neutrality, general interest, and neither the resources or the ability to mobilize them, respectively. See Appendix 3 for a description of the 10-point scale. Stakeholder attributes were based on answers to questions asked during the interview (Appendix 4) and were assessed according to the descriptions and categorizations described in Table 2. According to experts with prior experience of the study system and its resident communities, the three attributes are representative and efficient in determining a stakeholder's importance in the decision-making process involving an expanded protected area network. The analytical categorization was based on that of Mitchell et al. (1997) who prescribe using urgency, legitimacy, and power to assess "who and what really counts" in stakeholder theory. Here, urgency or a stakeholder's attentiongetting capacity, is substituted with the interest attribute because all groups studied were considered to have equal or similar urgency on account of their proximity to ENP. The interest attribute gives an indication of the stakeholder's willingness to participate in the expanded protected area concept and thus influence future decisions. Legitimacy denotes socially acceptable or normative appropriateness of stakeholder demands, i.e., expected structures of behaviors (Neville et al. 2011). Because assessing desirability and appropriateness of stakeholder viewpoints was not the aim of the study, and we only intend to ascertain the pragmatic or cognitive validity of stakeholder support or opposition of the concept, the legitimacy attribute was replaced by that of position.

\section{RESULTS}

\section{Stakeholder groups}

Twelve main stakeholder groups were identified based on differences in land use practices and their roles in the system under study (Table 3). Stakeholders were classified as "primary" $(\mathrm{n}=$
56) or "secondary" $(n=26)$ based on their proximity to ENP (whether they were located adjacent to the park or not), land tenure (private or communal), and how important they were to the decision-making process guiding integrated landscape management, i.e., their stake in the protected area expansion.

\section{Stakeholder attributes}

\section{Position}

Stakeholder positions on being incorporated into the conservation landscape vary from negative (oppose) to strongly positive (support). When the results of stakeholder position were assessed, opposition to being incorporated into the protected area landscape was found in the resettlement farmer, livestock farmer, and communal conservancy member primary stakeholder groups (score $=4$; Fig. 2a). However, when results were classified in relation to land use, i.e., commercial or subsistence livestock farming, consumptive wildlife use, tourism, and hunting, and not according to stakeholder roles in the system, we found opposition in the livestock production group (Fig. 2b). Livestock farmers directly adjacent to the park were in opposition to the concept of being part of the integrated conservation landscape. Although they did not score 1 (strongly negative and in opposition of the idea) and are categorized as negative (2 or 3 ), their opposition was offset by the more slightly negative or indifferent scores (4 or $5)$ of the majority of their group $(n=5)$.

\section{Interest}

Based on stakeholder responses to questions relating to the perceived advantages and disadvantages to being incorporated into the protected area landscape, interest scores varied across and within stakeholder groups. The median scores of each stakeholder group are depicted in Figure 3 where stakeholders are categorized on a 1-10 scale ranging from "no or minimal" to "primary" interest in being part of an integrated conservation landscape. Based on answers to open-ended questions, stakeholders were also grouped according to their stated interest in becoming part of the protected area landscape. Livestock farmers stated consumptive benefits such as "better quality grazing," "improved soil maintenance," and "rich underground 
Table 2. Description of stakeholder attributes used to categorize stakeholders.

\begin{tabular}{|c|c|}
\hline Attribute & Description \\
\hline Position $^{\dagger, \ddagger, \S}$ & $\begin{array}{l}\text { The stakeholder's level of support for or opposition to an expanded } \\
\text { protected area network } \\
\text { Ascertained by recording each person's stated position }\end{array}$ \\
\hline Interest ${ }^{\dagger,+,}$ & $\begin{array}{l}\text { The disadvantages and advantages of being part of the protected } \\
\text { area landscape } \\
\text { Obtained by combining each person's self-reported level of interest } \\
\text { toward the concept with their perceived costs and benefits to being } \\
\text { located adjacent to the Etosha National Park (descriptive). }\end{array}$ \\
\hline Power ${ }^{\dagger, *, \S}$ & $\begin{array}{l}\text { The resources a stakeholder is able to mobilize in order to express } \\
\text { their position } \\
\text { Involves a combination of stated alliances and interactions with } \\
\text { other stakeholders, resources available to oppose or support the } \\
\text { concept of conservation landscape around Etosha National Park } \\
\text { and each person's self-reported influence. }\end{array}$ \\
\hline Salience & $\begin{array}{l}\text { Stakeholder importance } \\
\text { Measured using a co-ordinate system in a 3-dimensional space } \\
\text { delineated by three axes, each axis representing one of the selected } \\
\text { attributes; namely stakeholder position on the integrated } \\
\text { conservation landscape concept, their interest therein, and their } \\
\text { relative power in having these realized }\end{array}$ \\
\hline
\end{tabular}

Categorization

supporting (strongly positive/positive)

neutral (slightly positive/indifferent/slightly negative) opposing (negative/strongly negative)

low (no to minimal interest)

medium (general interest)

high (primary interest)

low (neither the resources nor the ability to mobilize the resources)

medium (having one of either the resources or the ability to mobilize them)

high (both the resources and the ability to mobilize the resources)

$$
S=\sqrt{a^{2}+b^{2}+c^{2}}
$$

Where $\mathrm{S}=$ salience and $\mathrm{a}, \mathrm{b}, \mathrm{c}=$ the values of the selected attributes. Such that:

$$
\text { Salience }=\sqrt{\text { position }^{2}+\text { interest }^{2}+\text { power }^{2}}
$$

\section{†chmeer (1999)}

"Varvasovszky and Brugha (2000)

§Jepson and Eskerod (2009)

Eden and Ackerman (1998)

Fig. 2. (a) Position scores of all stakeholder groups, i.e., both primary and secondary stakeholders, grouped according to stakeholder roles in the study system, i.e., conservancy members, livestock farmers, park management, NGOs, experts, etc. (b) Position scores of only the primary stakeholder groups classified according to land use, i.e., livestock production, protected area management, consumptive resource use, and nonconsumptive resource use and combined livestock and wildlife use. (Position score $1=$ a strongly negative/opposed stakeholder group and $10=$ a strongly positive/supportive stakeholder group, when considering their perspectives on an expanded protected area network, and their inclusion therein).

a

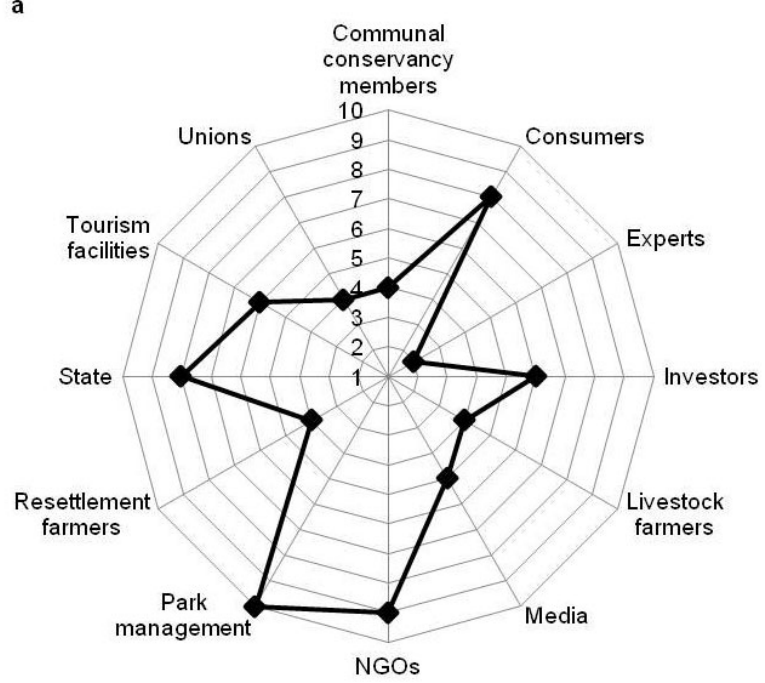

b

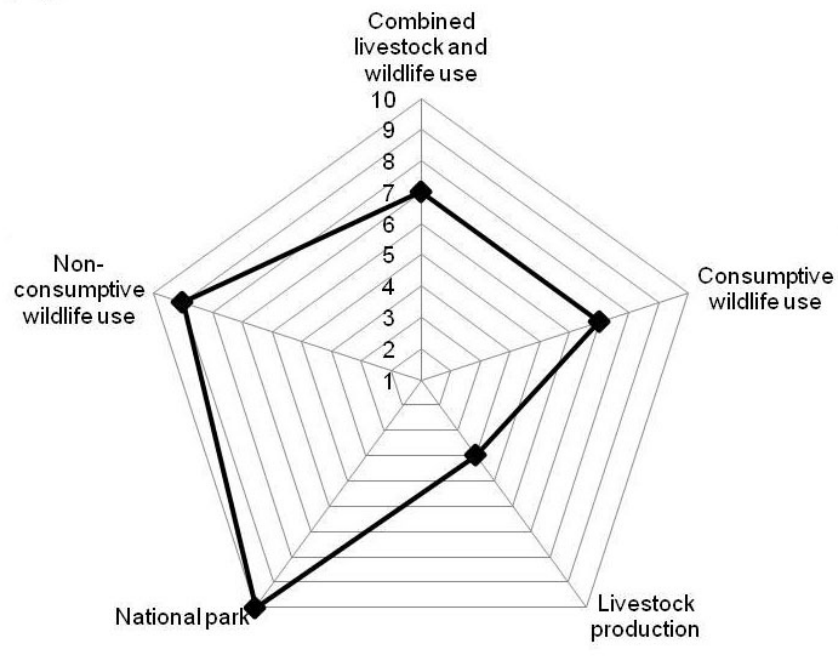


Table 3. Stakeholder groups involved in the expansion of the protected area network around Etosha National Park (ENP).

\begin{tabular}{|c|c|c|c|}
\hline Stakeholder & Stakes & $\begin{array}{l}\text { Stakeholder effect on expanded protected } \\
\text { area network }\end{array}$ & $\begin{array}{l}\text { Expanded protected area network effect } \\
\text { on stakeholder }\end{array}$ \\
\hline \multirow[t]{4}{*}{ Livestock farmers } & $\begin{array}{l}\text { Own/manages land adjacent to the } \\
\text { ENP }\end{array}$ & $\begin{array}{l}\text { Definitive border (hard fence) between } \\
\text { protected area and livestock farm }\end{array}$ & Predation \\
\hline & $\begin{array}{l}\text { Livestock production (commercial } \\
\text { and subsistence) }\end{array}$ & $\begin{array}{l}\text { Artificial water points attract game/ } \\
\text { wildlife from ENP }\end{array}$ & $\begin{array}{l}\text { Veterinary cordon fence requires a } 21 \text { day } \\
\text { quarantine on all livestock headed to the } \\
\text { market }\end{array}$ \\
\hline & \multirow[t]{2}{*}{ Direct neighbor } & Livestock attracts predators & Fence damage \\
\hline & & Domestic animal diseases & Pressure by other neighbors to convert \\
\hline
\end{tabular}

Tourism facilities, e.g., trophy/hunting concessions

Communities (rural) Conservancies

Resettlement farmers

Government local, regional, and national

Experts, research, and professional institutions/ associations

Consumers tourists/hunters
Own/manages land adjacent to the ENP

Provide safe and pleasurable nature/ hunting experience (photographic tourism, game safaris, camping accommodation, etc.

Direct neighbor

Responsible for sustainable use of natural resources and land

Consumers of natural resources Direct neighbor

Manages land adjacent to ENP

Livestock production (subsistence)

Consumers of natural resources Direct neighbor

Legislation, policy, and strategy development

Planning processes and control/ enforcement

Administration, financing, and surveillance

Establish/share best practice in sustainable resource use, conservation and development, hunting and tourism

Pays for and makes use of natural products and services (tangible and intangible)
Indirectly affects the system through

choices made pertaining to the

environment

Provide proconservation land use practices

Soft border between the park and neighboring farms

Refuge for wildlife (e.g., semiapex predators, small mammals)

Buffer for wildlife diseases

Indirectly affects the system through

choices made pertaining to the

environment

Practice proconservation land use alongside traditional livestock production and crop planting/plant harvesting Soft border between the park and neighboring farms

Refuge for wildlife (e.g., semiapex predators, small mammals)

Buffer for wildlife diseases

Provide hunting concessions to private hunters

Definitive border (hard fence) between protected area and livestock farms

Artificial water points attract game/ wildlife from ENP

Livestock attracts predators

Domestic animal diseases

Indirectly affects the system through

choices made pertaining to the

environment

Can affect the expansion process directly

via legislation, regulation, and

compliance

Local authority affects the process

directly via planning, monitoring, and

providing subsidies/compensation

Affect the social-ecological system indirectly through provision of guidance, suggestions, and support, increased interest in the expansion of protected areas

Can affect the social-ecological system indirectly by over-use/exploitation of resources
Likelihood of increased tourism in the area

Likelihood of increased wildlife in the area

Would be expected to maintain and monitor expanded protected area

Likelihood of increased tourism in the

Likelihood of increased wildlife in the area

Increase in human-wildlife conflict Improvement in infrastructure

\section{Predation}

Veterinary cordon fence requires a 21 day quarantine on all livestock headed to the market

Fence damage

Affected directly by development process, likelihood of conservation success, and social stability objectives

No major influence unless advice is needed

Affects human safety and property security 
Media

NGOs

Park Management

Foreign investors/ insurance companies

Farmers/Agricultural Union
May highlight conservation/ development issues

Nonelected representation if wildlife, conservation, sectors of the public

Establishes, manages, monitors expanded protected area

Provision of funds/insurance of properties (applicable to private land)
Disturb community dynamics and ecosystem services (e.g., pollution) Potentially higher effect if urgent claims or effects were ever to become present (e. g., death due to problem animals, poaching, poisoning of problem animals)

Possible indirect effects via lobbying of safety or planning issues

Become more salient if any urgent claim or effects become present

Direct affect by protecting area under their jurisdiction

Need to build/maintain relationships with other stakeholders

Indirect effects by withdrawal of support if land managers perceived to be acting unfavorably

Indirect affect due to investigation of environmental and livestock production records (e.g., level of predation/length of quarantine affects premiums)

Potential indirect affect if unions lobby against the loss of jobs, income, and safety of livestock farms
Affected by regulation authority (e.g., permits)

No influence

No influence other than an example of good practice

Directly affected through working procedures Increased jurisdiction

Can lose money invested/support if production/conservation poor Only affected if environmental liability arises or if conservation effort diminishes

No influence their employees, and co-ops

water reserves." The tourism facilities mentioned nonconsumptive benefits such as "increased wildlife sightings," "proximity to a renowned protected area," and "existence value." Those tourism facilities that provided game and trophy hunting experiences or the private landowners that practiced combination farming, i.e. livestock and game production, cited both consumptive and nonconsumptive benefits related to being part of the conservation landscape.

Fig. 3. Median interest scores for the different stakeholder groups, including both primary and secondary stakeholders, classified according to stakeholder roles in the study system, i. e., conservancy members, livestock farmers, park management, NGOs, experts, etc. (Interest score $1=$ no or minimal interest to $10=$ primary interest in being incorporated into an expanded protected area landscape around Etosha National Park.)

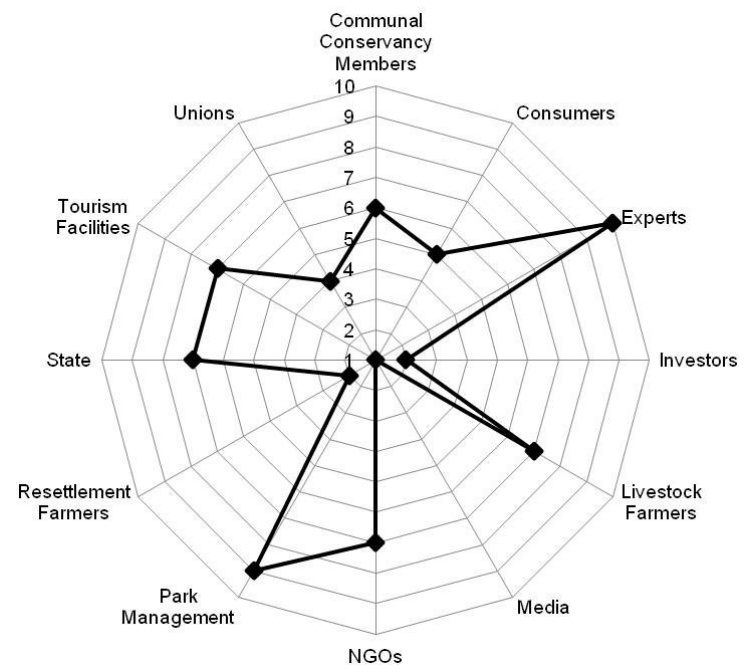

The communal conservancy stakeholder group stated that being part of the larger conservation area will benefit them tangibly, $i$. e., provisioning ecosystem services such as fuel wood and forage for livestock, and intangibly, i.e., cultural and regulating ecosystem services, including hunting and tourism as well as flood and drought control. Unlike the other stakeholder groups, communal conservancy members are legally bound to maintain and monitor natural resources on their land and many mentioned this obligation during interviews or informal conversations. Their interests span consumptive and nonconsumptive benefits being derived from the park, and also a concern, as determined by policy, for the ecological health of the ENP and its surroundings. Also stated by several participants in various stakeholder groups were certain "collateral benefits" of flanking the park, including availability of roads, clinics, and schools in the area.

The most commonly cited disadvantage, both within stakeholder groups and amongst all respondents, related to the ENP fence. The physical fence was viewed as ineffective in preventing humanwildlife conflict because a lack of maintenance, fire and structural damage caused by animals seeking forage and/or water has left some sections permeable. Several respondents mentioned disadvantages and threats to the ENP in the event of an expanded protected area. These mostly included concerns surrounding increased poaching incidents, human encroachment, land conversion, invasive species, e.g., common impala (Aepyceros melampus), and illegal livestock grazing and fuel wood collection in the park because of the permeability of the fence.

\section{Power}

The majority of the power rests with private land owners directly adjacent to the ENP, because under freehold title they are entitled to use their land as they deem fit. Land managers, i.e., those in charge of properties but who do not own or have any financial shares in the establishment, and private landowners not directly 
bordering the park, the government, and park management, all fall in to the medium range of power. As secondary stakeholders, investors and insurance companies, unions and NGOs had low power scores. Communal conservancy members and resettlement farmers, although primary stakeholders, had low power scores because they do not own the land they are managing and have neither the resources nor, in most cases, the ability to mobilize them to decisively determine outcomes regarding protected area expansion.

\section{Salience}

The median values of each stakeholder group's attribute estimates are presented in Table 4. Key stakeholder groups in the protected area landscape were identified as those with the highest scores; ENP management $(S=15.2)$, tourism facilities $(S=13.3)$, and the state $(S=13.3)$. Also of importance were livestock farmers ( $S=12.1)$, experts $(S=11.8)$, and NGOs $(S=11.8)$. The majority of stakeholder groups scored high on the $x$ and $y$ axes where position and interest intercept, but because of their lower power scores their placement on the $z$ axis shortened their distance from the starting point, lowering their salience. Primary stakeholders such as communal conservancy members, who expressed interest and support for the concept of an integrated landscape, had lower salience estimates than other primary stakeholders also directly neighboring the park (Fig. 4). The group with the highest salience, ENP management $(S=15.2)$, directs the processes of the park and any future expansion. The state had the second highest score $(S=13.3)$. Both the state and ENP management are responsible for protected area planning and implementation and in effect, they should be responsible for conducting a stakeholder analysis, instead of being a subject thereof. Tourism facilities are thus viewed as having the highest salience, effectively $(S=13.3)$.

Table 4. Median stakeholder attribute values and calculated salience values of respondents involved in the expansion of the protected area network around Etosha National Park.

\begin{tabular}{|c|c|c|c|c|}
\hline \multirow[b]{2}{*}{ Stakeholder group } & \multicolumn{3}{|c|}{ Attributes } & \multirow{2}{*}{$\begin{array}{c}\text { Salience } \\
S=\sqrt{\left(a^{2}+b^{2}+c^{2}\right)}\end{array}$} \\
\hline & position & interest & power & \\
\hline Livestock farmers $(\mathrm{n}=8)$ & 4 & 7 & 9 & 12.1 \\
\hline Tourism facilities $(\mathrm{n}=12)$ & 8 & 7 & 8 & 13.3 \\
\hline $\begin{array}{l}\text { Communal conservancy: } \\
\neq \text { Khoadi-//Hôas }(\mathrm{n}=12)\end{array}$ & 4 & 5.5 & 4 & 7.9 \\
\hline Ehi Rovipuka $(\mathrm{n}=12)$ & 5 & 2 & 4 & 6.7 \\
\hline $\begin{array}{l}\text { Resettlement farmers }(\mathrm{n}= \\
\text { 12) }\end{array}$ & 4 & 2 & 3 & 5.4 \\
\hline ENP management $(\mathrm{n}=5)$ & 10 & 9 & 7 & 15.2 \\
\hline State $(n=4)$ & 8 & 7 & 8 & 13.3 \\
\hline Experts $(\mathrm{n}=2)$ & 2 & 10 & 6 & 11.8 \\
\hline NGOs $(n=6)$ & 9 & 7 & 3 & 11.8 \\
\hline Unions $(\mathrm{n}=2)$ & 5 & 1 & 1 & 5.2 \\
\hline Consumers $(n=4)$ & 8 & 5 & 2 & 9.6 \\
\hline $\begin{array}{l}\text { Insurance/investors }(n= \\
\text { 1) }\end{array}$ & 6 & 2 & 2 & 6.6 \\
\hline Media $(n=2)$ & 4 & 4 & 2 & 6.0 \\
\hline
\end{tabular}

Group specific cumulative values for interest revealed that ENP management and scientific/research experts were the most supportive of the expanded protected area concept (Appendix 5). As a group, livestock farmers, and ENP management, perceived themselves as having primary interests in the conservation landscape; whereas livestock farmers and the state, cumulatively, had the highest power scores. Livestock farmers mostly $(63 \%)$ scored as moderately supportive, indifferent, and slightly opposing the concept, while half of the group had a general to high interest therein and the rest scored as having a high to primary interest.

\section{DISCUSSION}

The planning and implementation of protected areas involves different policy sectors and affects different land use categories. According to Grimble and Wellard (1997), the explicit consideration of trade-offs between different policy objectives and conflicts between stakeholder interests facilitates effective project design and improves the likelihood of success thereof, aiding in the assessment of outcomes and avoiding the unexpected. The collective governance of natural systems involves multiple uses and users of resources. Thus by analyzing the interests and impacts of intervention of different stakeholders, stakeholder analysis can help ensure that potential costs and benefits are equitably considered and reach the intended parties.

Fig. 4. Scatter plot of stakeholder salience in a threedimensional co-ordinate system. The median position scores of all stakeholder groups are plotted on the $\mathrm{x}$ axis, the median interest scores on the $y$ axis, and the median power scores on the $\mathrm{z}$ axis. The markers indicate where stakeholder attributes intersect, i.e., circles indicate where position and power intersect, squares indicate where position and interest intersect, and crosses indicate where power and interest intersect. The triangles show stakeholder salience, where all three points of stakeholder attributes intersect. The size and shade of the triangle depicts the difference in salience among the different stakeholder groups, i.e., the groups with larger, darker triangles have higher salience scores.

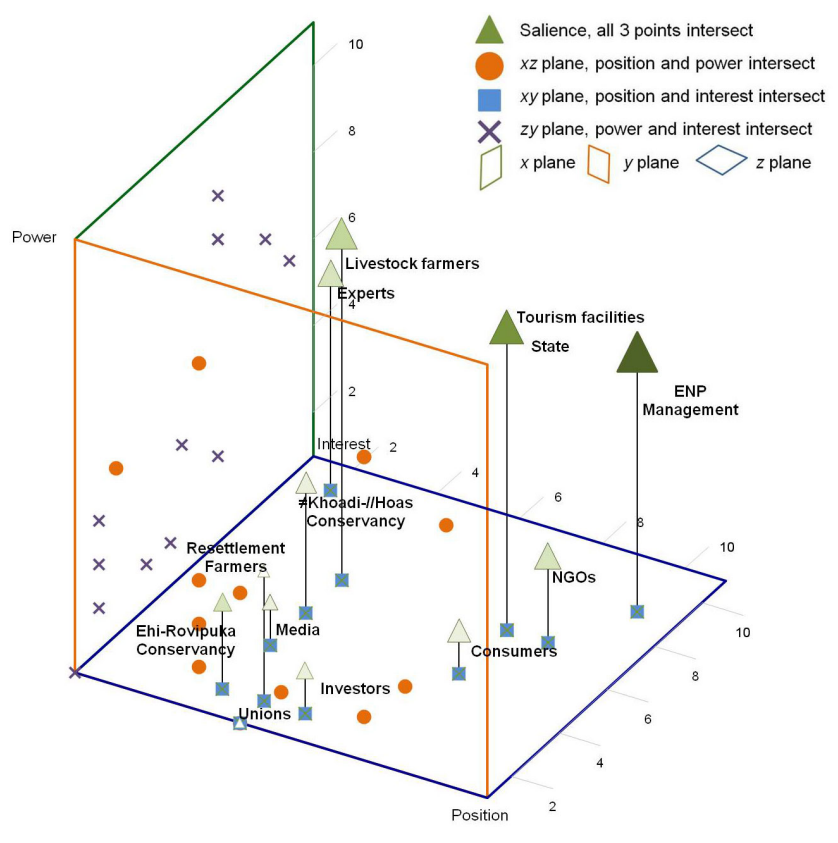


Stakeholder analysis was used to identify and categorize stakeholder groups surrounding the ENP and those potentially involved in the extension of the current protected area system. Based on their proximity to the national park, private landowners, communal conservancy members, and resettlement farmers together with ENP management, were identified as primary stakeholders. Local residents and local level protected area staff who are imperative to the preservation of cultural and natural landscapes (Furze et al. 1996, Borrini-Feyerabend et al. 2004) have also been highlighted as important in the joint process of conservation and development by studies in the field of participatory planning (Hannah et al. 1998, Wells and McShane 2004, Treves et al. 2009). The selection of stakeholders based only on proximity, however, obscures the variable viewpoints held by resident communities (Reed et al. 2009).

Once identified, matrices are commonly used to categorize stakeholders by grouping them according to their relative interest and influence. Reed et al. (2009) applied interest-influence matrices in describing the principle ways in which stakeholders involved in the UK Rural Economy and Land Use Programme related to various aspects of the project. They found that although such matrices provided quantitative information about the relative interest and influence of different stakeholders, the information remains subjective, containing many hidden assumptions that fail to capture the position of stakeholders regarding the matter at stake, and as such have limited replicability. They conclude that "by capturing qualitative information about why different stakeholders have a particular interest (and specifically what this interest is), and why certain stakeholders have more influence than others (and in what contexts), the information gathered is likely to be more useful and replicable" (Reed et al. 2009:1946). Our study therefore categorized stakeholders according to attributes of position, interest and power.

When opposition to the concept of being incorporated into the conservation landscape was assessed based on land use, i.e., commercial or subsistence livestock farming, consumptive or nonconsumptive wildlife use, combined livestock farming and wildlife use, opposition was linked to dependence on livestock farming. In addition to assessing position on being incorporated into the conservation landscape, we assessed stakeholders' perceived advantages and disadvantages of being part of the protected area matrix, i.e., interests. The combination of interest and position provided a clearer picture of supportive stakeholders and the reasons for their support.

Supportive stakeholders can be viewed as collaborators (Varvasovszky and Brugha 2000), particularly when their viewpoints have been incorporated in the initial planning phases and they have a sense of ownership over the project. Strong supporters for an integrated conservation landscape include those particularly focused on nonconsumptive activities. Those only moderately supportive of the concept included tourism facilities that practiced combined game and livestock production because of the risk of predation on livestock. These moderately supportive, so-called "fence-sitters" could be important in generating support for the protected area network if the areas surrounding the ENP are to be incorporated (see Rastogi et al. 2014).
Stakeholder groups that are categorized as neutral and slightly negative still need to be considered because they are directly affected by any decisions regarding the conservation landscape. Opposition to the expanded protected area concept is stronger among livestock farmers, on private and communal land, than among other land use types (consumptive and nonconsumptive tourism and combination farming). Other studies involving protected areas and their surrounding farmlands also identified farmers as main opponents (Stoll-Kleemann 2001 $a, b$, Arnberger and Schoissengeier 2012, Nastran 2015). Because farmers and protected areas depend on similar natural benefits provided by landscapes, e.g., provisioning and regulating ecosystem services such as clean water, pastures, and soil maintenance, they are often in conflict with each other for these benefits. This emphasizes the importance of considering ecosystem services used by stakeholders in the conservation landscape decision-making process (de Groot et al. 2010, Darvill and Lindo 2016).

Regarding perceived interests of being part of the protected area network, diverse opinions were expressed within the same stakeholder groups. In the groups that depended on a combination of wildlife use and livestock farming, mentioned advantages of being adjacent to the park included consumptive and nonconsumptive benefits being derived from an increase in wildlife populations, namely the potential increase in hunting quotas and an increase in tourism, respectively. Within these groups, increased human-wildlife conflict was also considered a disadvantage, because the predation on livestock and the destruction of crops threaten livelihoods. This indicates diversity in opinion on the same issue, because of different perceptions surrounding the benefits of living adjacent to a protected area. Stakeholder dynamics within and between groups can thus not be overlooked.

Individual estimates of stakeholder attributes may also change over time, depending on the social-ecological or political situation (Neville et al. 2011, Van Assche et al. 2011). In the current study, the land tenure systems in place affects power dynamics. Under freehold title, private farmers have absolute land rights over their properties, while communal conservancy members and resettlement farmers, under customary tenure, are authorized by traditional leaders with the land and resources belonging to the state. This affects their decision-making ability in the landscape, particularly the mobilization of resources to support or oppose any changes (Mitchell et al. 1997). Other stakeholder analyses have incorporated stakeholder attributes of legitimacy: whether stakeholders have legitimate demands, and urgency, whether stakeholder's claims call for immediate attention (Neville et al. 2011, Nastran 2014). In the southern African context, the combination of interest, position, and power, as applied here, is sufficient in that it considers the diverse socio-political and ecological variables present in the landscape.

Even those opposed to the expanded protected area, such as livestock farmers, and those with less power to effect change, such as conservancy members and resettlement farmers, need to be included in the decision-making process, and their concerns about being incorporated into the conservation landscape taken into account (Suŝkevičs et al. 2013, Nastran 2015). Under mobilization, such opposing and less powerful groups may be able to sway opinions and it is therefore important to identify their 
concerns and seek ways to address them, solving conflicts proactively. A larger, diverse and connected landscape is more resilient than a smaller, fragmented one (Cumming 2011). This is critical in arid southern Africa, where diversified resource dependence and a broader livelihood base provide greater safety nets for more people (Shackleton and Shackleton 2004, O'Farrell et al. 2010). The support and collaboration of (all) key stakeholders is therefore essential for a successful protected area system, supporting a variety of land uses and resource users.

\section{CONCLUSION}

Land use type affects stakeholder position concerning being incorporated into the protected area system, with livestock farmers mostly opposing the concept. All primary stakeholders cite interest therein, however, with power greatly affecting stakeholder salience because land tenure prescribes the roles and activities of stakeholders on the various properties surrounding the ENP. The interpretation of stakeholder analysis varies across disciplines, with stakeholder participation and empowerment presenting a central theme. In most cases, stakeholders are categorized according to their power, legitimacy, and urgency, with the assumption that these attributes indicate the amount and type of attention stakeholders need. We argue that this only provides a static view of the situation and highlight the need to understand the dynamic nature of stakeholder attributes instead. Furthermore, only a limited amount of empirical research adopts the perspective of the stakeholders to understand stakeholder attributes and how these potentially influence decision making. In this paper, we combine the identification and categorization of stakeholders with stakeholder perspectives on position, interest, and power in the expansion of the protected area network, and thus their influence in the outcome. The paper extends existing research by assessing the dynamic nature of stakeholder salience in protected area decision making and understanding the differences within and between stakeholder groups. Ultimately, recognizing stakeholder perspectives can enable practitioners and policy makers to better understand and manage stakeholder inclusion in landscape management.

Responses to this article can be read online at: http://www.ecologyandsociety.org/issues/responses. $\mathrm{php} / 10790$

\section{Acknowledgments:}

Thank you to all the study participants for sharing their valuable time, observations, and perspectives and the anonymous reviewers for their helpful and constructive comments. The research was conducted with funding provided by the International Foundation for Science (grant number S/5299-1), the Namibia Environmental Investment Fund, and the Harry Crossley Foundation (MET Research Permit 1828/2013-16). We acknowledge support from the International Offices of Stellenbosch University (namely R. Kotze) and Humboldt-Universität zu Berlin (namely U. Hans) and the German Academic Exchange Service (DAAD) for supporting this study under the umbrella project "Quality Network Biodiversity in Sub-Sahara Africa” (project number: 20010181 PI: Prof. Zeller) and to the Zwillenberg-Tietz Stiftung and the project "Land use contrasts and edge effects - a comparative approach." KJE acknowledges the South African National Research Foundation, NRF (grant number 103841). LMM and KJE recognize the Southern African Program on Ecosystem Change and Society (SAPECS) for their invaluable input.

\section{LITERATURE CITED}

Andrade, G. S. M., and J. R. Rhodes. 2012. Protected areas and local communities: an inevitable partnership toward successful conservation strategies? Ecology and Society 17(4):14. http://dx. doi.org/10.5751/ES-05216-170414

Arnberger, A., and R. Schoissengeier. 2012. The other side of the border: Austrian local residents' attitudes towards the neighbouring Czech Šumava National Park. Journal for Nature Conservation 20(3):135-143. https://doi.org/10.1016/j.jnc.2012.01.005

Bengtsson, J., P. Angelstam, T. Elmqvist, U. Emanuelsson, C. Folke, M. Ihse, F. Moberg, and M. Nyström. 2003. Reserves, resilience and dynamic landscapes. Ambio 32(6):389-396. http:// dx.doi.org/10.1579/0044-7447-32.6.389

Bennett, E. M., W. Cramer, A. Begossi, G. Cundill, S. Diaz, B. N. Egoh, I. R. Geijzendorffer, C. B. Krug, S. Lavorel, E. Lazos, L. Lebel, B. Martín-López, P. Meyfroidt, H. A. Mooney, J. L. Nel, U. Pascual, K. Payet, N. Pérez Harguindeguy, G. D. Peterson, A.H. Prieur-Richard, B. Reyers, P. Roebeling, R. Seppelt, M. Solan, P. Tschakert, T. Tscharntke, B. L. Turner II, P. H. Verburg, E. F. Viglizzo, P. C. L. White, and G. Woodward. 2015. Linking biodiversity, ecosystem services, and human well-being: three challenges for designing research for sustainability. Current Opinions in Environmental Sustainability 14:76-85. https://doi. org/10.1016/j.cosust.2015.03.007

Berry, H. H. 1997. Historical review of the Etosha region and its subsequent administration as a national park. Madoqua 20 (1):3-12.

Borrini-Feyerabend, G., A. Kothari, and G. Oviedo. 2004. Indigenous and local communities and protected areas: towards equity and enhanced conservation. Guidance on policy and practice for co-managed protected areas and community conserved areas. Best Practice Protected Area Guidelines Series No. 11. International Union for Conservation of Nature, Gland, Switerland.

Brown, J., and N. Bird. 2011. Sustainable natural resource management in Namibia: successful community-based wildlife conservation. Development Progress Report. Overseas Development Institute, London, UK.

Brown, C., S. Canney, R. Martin, and P. Tarr. 2005. Strengthening the system of national protected areas project in Namibia. Subcontract No. 3: Conservation Needs Assessment, Revised Report. The Environment and Development Group, Oxford, UK.

Brugha, R., and Z. Varvasovszky. 2000. Stakeholder analysis: a review. Health Policy and Planning 15(3):239-246. https://doi. org/10.1093/heapol/15.3.239

Chambers, R. 1997. Whose reality counts? Putting the first last. Intermediate Technology Publications, London, UK. http://dx. doi.org/10.3362/9781780440453 
Chape, S., J. Harrison, M. Spalding, and I. Lysenko. 2005. Measuring the extent and effectiveness of protected areas as an indicator for meeting global biodiversity targets. Philosophical Transactions of the Royal Society of London Series B: Biological Sciences 360(1454):443-455. https://doi.org/10.1098/rstb.2004.1592

Chevalier, J. M., and D. Buckles. 1999. Conflict management: a heterocultural perspective. Pages 13-44 in D. Buckles, editor. Cultivating peace: conflict and collaboration in natural resource management. International Development Research Centre and World Bank Institute, Washington, D.C., USA.

Chitakira, M., E. Torquebiau, W. Fergusson, and K. Mearns. 2015. Suggesting an interdisciplinary framework for the management of integrated production and conservation landscapes in a transfrontier conservation area in southern Africa. Pages 265-277 in N. Benkeblia, editor. Agroecology, ecosystems, and sustainability. CRC, Boca Raton, Florida, USA.

Clarkson, M. E. 1995. A stakeholder framework for analyzing and evaluating corporate social performance. Academy of Management Review 20(1):92-117. http://dx.doi.org/10.5465/ amr.1995.9503271994

Creswell, J. W. 2009. Editorial: mapping the field of mixed methods research. Journal of Mixed Methods Research 3 (2):95-108. http://dx.doi.org/10.1177/1558689808330883

Cumming, G. S. 2011. Spatial resilience in social-ecological systems. Springer. Dordrecht, Netherlands. http://dx.doi. org/10.1007/978-94-007-0307-0

Darvill, R., and Z. Lindo. 2016. The inclusion of stakeholders and cultural ecosystem services in land management trade-off decisions using an ecosystem services approach. Landscape Ecology 31(3):533-545. http://dx.doi.org/10.1007/s10980-015-0260$\mathrm{y}$

de Groot, R. S., R. Alkemade, L. Braat, L. Hein, and L. Willemen. 2010. Challenges in integrating the concept of ecosystem services and values in landscape planning, management and decision making. Ecological Complexity 7(3):260-272. https://doi. org/10.1016/j.ecocom.2009.10.006

DeFries, R., A. Hansen, A. C. Newton, and M. C. Hansen. 2005. Increasing isolation of protected areas in tropical forests over the past twenty years. Ecological Applications 15(1):19-26. http://dx. doi.org/10.1890/03-5258

DeFries, R., and C. Rosenzweig. 2010. Toward a whole-landscape approach for sustainable land use in the tropics. Proceedings of the National Academy of Sciences 107:19627-19632. http://dx.doi. org/10.1073/pnas.1011163107

Dougill, A. J., E. D. G. Fraser, J. Holden, K. Hubacek, C. Prell, M. S. Reed, S. Stagl, and L. C. Stringer. 2006. Learning from doing participatory rural research: lessons from the Peak District National Park. Journal of Agricultural Economics 57(2):259-275. http://dx.doi.org/10.1111/j.1477-9552.2006.00051.x

Eden, C., and F. Ackermann. 1998. Making strategy: the journey of strategic management. Sage, London, UK.

Fabricius, C., E. Koch, H. Magome, and S. Turner. 2004. Rights, resources and rural development: community-based natural resource management in southern Africa. Earthscan, London, UK.
Foley, J. A., R. DeFries, G. P. Asner, C. Barford, G. Bonan, S. R. Carpenter, F. S. Chapin, M. T. Coe, G. C. Daily, H. K. Gibbs, J. H. Helkowski, T. Holloway, E. A. Howard, C. J. Kucharik, C. Monfreda, J. A. Patz, I. C. Prentice, N. Ramankutty, and P. K. Snyder. 2005. Global consequences of land use. Science 309 (5734):570-574. http://dx.doi.org/10.1126/science.1111772

Freeman, R. E. 1984. Strategic management: a stakeholder approach. Basic Books, New York, New York, USA. http://dx. doi.org/10.1017/CBO9781139192675

Friedman, A. L., and S. Miles. 2002. Developing stakeholder theory. Journal of Management Studies 39(1):1-21. http://dx.doi. org/10.1111/1467-6486.00280

Friedman, A. L., and S. Miles. 2004. Stakeholder theory and communication practice. Journal of Communication Management 9(1):7-9.

Friedman, A. L., and S. Miles. 2006. Stakeholders: theory and practice. Oxford University Press, Oxford, UK.

Furze, B., T. De Lacy, and J. Birckhead. 1996. Culture, conservation and biodiversity: the social dimension of linking local level development and conservation through protected areas. John Wiley and Sons, Chichester, UK.

Gaston, K. J., S. F. Jackson, L. Cantú-Salazar, and G. Cruz-Piñón. 2008. The ecological performance of protected areas. Annual Review of Ecology, Evolution, and Systematics 39:93-113. https:// doi.org/10.1146/annurev.ecolsys.39.110707.173529

Grimble, R., and K. Wellard. 1997. Stakeholder methodologies in natural resource management: a review of principles, contexts, experiences and opportunities. Agricultural Systems 55 (2):173-119. https://doi.org/10.1016/S0308-521X(97)00006-1

Guerbois, C., E. Chapanda, and H. Fritz. 2012. Combining multiscale socio-ecological approaches to understand the susceptibility of subsistence farmers to elephant crop raiding on the edge of a protected area. Journal of Applied Ecology 49 (5):1149-1158. http://dx.doi.org/10.1111/j.1365-2664.2012.02192. $\underline{\mathrm{X}}$

Hannah, L., B. Rakotosamimanana, J. Ganzhorn, R. A. Mittermeier, S. Olivieri, L. Iyer, S. Rajaobelina, J. Hough, F. Andriamialisoa, I. Bowles, and G. Tilken. 1998. Participatory planning, scientific priorities, and landscape conservation in Madagascar. Environmental Conservation 25(1):30-36. http://dx. doi.org/10.1017/S0376892998000071

Heller, N. E., and E. S. Zavaleta. 2009. Biodiversity management in the face of climate change: a review of 22 years of recommendations. Biological Conservation 142(1):14-32. http:// dx.doi.org/10.1016/j.biocon.2008.10.006

Hutchinson, A. J., L. H. Johnston, and J. D. Breckon. 2010. Using QSR-NVivo to facilitate the development of a grounded theory project: an account of a worked example. International Journal of Social Research Methodology 13(4):283-302. https://doi. org/10.1080/13645570902996301

Jepsen, A. L., and P. Eskerod. 2009. Stakeholder analysis in projects: challenges in using current guidelines in the real world. International Journal of Project Management 27(4):335-343. https://doi.org/10.1016/j.ijproman.2008.04.002 
Jokisch, A. 2009. A buffer for Etosha: the attitudes towards a buffer zone on private farmland at the south-western border of the Etosha National Park (Namibia) and chances for its implementation. Dissertation. Universität Oldenburg, Germany.

Jones, B. T. 2010. The evolution of Namibia's communal conservancies. Pages 106-120 in F. Nelson, editor. Community rights, conservation and contested land: the politics of natural resource governance in Africa. Earthscan, London, UK.

Joppa, L. N., S. R. Loarie, and S. L. Pimm. 2008. On the protection of "protected areas." Proceedings of the National Academy of Sciences 105(18):6673-6678. https://doi.org/10.1073/pnas.0802471105

Kareiva, P., and M. Marvier. 2012. What is conservation science? BioScience 62(11):962-969. https://doi.org/10.1525/bio.2012.62.11.5

Kothari, A. 2008. Protected areas and people: the future of the past. Parks 17(2):23-34. [online] URL: https://www.iucn.org/sites/ dev/files/import/downloads/kothari_article_parks_17_2.pdf

Lindsey, P. A., C. P. Havemann, R. Lines, L. Palazy, A. E. Price, T. A. Retief, T. Rhebergen, and C. van der Waal. 2013. Determinants of persistence and tolerance of carnivores on Namibian ranches: implications for conservation on Southern African private lands. PLoS ONE 8(1):e52458. https://doi. org/10.1371/journal.pone.0052458

Lindsey, P. A., V. R. Nyirenda, J. I. Barnes, M. S. Becker, R. McRobb, C. J. Tambling, W. A. Taylor, F. G. Watson, and M. t'Sas-Rolfes. 2014. Underperformance of African protected area networks and the case for new conservation models: insights from Zambia. PLoS ONE 9(5):e94109. https://doi.org/10.1371/ journal.pone.0094109

Lockwood, M. 2010. Good governance for terrestrial protected areas: a framework, principles and performance outcomes. Journal of Environmental Management 91(30):754-766. http://dx. doi.org/10.1016/j.jenvman.2009.10.005

Lockwood, M., G. L. Worboys, and A. Kothari. 2012. Managing protected areas: a global guide. Earthscan, London, UK. http:// dx.doi.org/10.4324/9781849771900

Millennium Ecosystem Assessment (MA). 2005. Ecosystems and human well-being: synthesis. Island, Washington, D.C., USA.

Mannetti, L. M., T. Göttert, U. Zeller, K. J. Esler. 2017. Expanding the protected area network in Namibia: an institutional analysis. Ecosystem Services 28(Part B):207-218. https://doi.org/10.1016/j.ecoser.2017.08.008

Mendelsohn, J. 2006. Farming systems in Namibia. Research and Information Services of Namibia (RAISON), Windhoek, Namibia.

Mendelsohn, J., A. Jarvis, C. Roberts, and T. Robertson. 2003. Atlas of Namibia: a portrait of the land and its people. David Philip Publishers, Cape Town, South Africa.

Ministry of Environment and Tourism (MET). 2010. State of protected areas in Namibia: a review of progress and challenges. Ministry of Environment and Tourism, Directorate of Parks and Wildlife Management, Windhoek, Namibia.

Ministry of Environment and Tourism (MET). 2014. Fifth National Report to the Convention on Biological Diversity
(2010-2014). Ministry of Environment and Tourism, Directorate of Parks and Wildlife Management, Windhoek, Namibia.

Mitchell, R. K., B. R. Agle, and D. J. Wood. 1997. Toward a theory of stakeholder identification and salience: defining the principle of who and what really counts. Academy of Management Review 22(4):853-886. http://dx.doi.org/10.2307/259247

Myers, N., R. A. Mittermeier, C. G. Mittermeier, G. A. B. da Fonseca, and J. Kent. 2000. Biodiversity hotspots for conservation priorities. Nature 403:853-858. https://doi.org/10.1038/35002501

Namibian Association of CBNRM Support Organisations (NACSO). 2014. The state of community conservation in Namibia: a review of communal conservancies, community forests and other CBNRM initiatives. Annual Report 2013. Namibian Association of CBNRM Support Organisations (NACSO), Windhoek, Namibia.

Namibian Association of CBNRM Support Organisations (NACSO). 2015. The state of community conservation in Namibia: a review of communal conservancies, community forests and other CBNRM initiatives (2014/15 Annual Report). Namibian Association of CBNRM Support Organisations (NACSO), Windhoek, Namibia.

Namibian Association of CBNRM Support Organisations (NACSO). 2016. The state of community conservation in Namibia: a review of communal conservancies, community forests and other CBNRM initiatives (2016 Annual Report). Namibian Association of CBNRM Support Organisations (NACSO), Windhoek, Namibia.

Namukonde, N., and R. N. Kachali. 2015. Perceptions and attitudes of local communities towards Kafue National Park, Zambia. Parks 21(2):25-36. http://dx.doi.org/10.2305/IUCN. CH.2014.PARKS-21-2NN.en

Nastran, M. 2014. Stakeholder analysis in a protected natural park: case study from Slovenia. Journal of Environmental Planning and Management 57(9):1359-1380. https://doi.org/10.1080/0964$\underline{0568.2013 .808608}$

Nastran, M. 2015. Why does nobody ask us? Impacts on local perception of a protected area in designation, Slovenia. Land Use Policy 46:38-49. https://doi.org/10.1016/j.landusepol.2015.02.001

Naughton-Treves, L., M. B. Holland, and K. Brandon. 2005. The role of protected areas in conserving biodiversity and sustaining local livelihoods. Annual Review of Environment and Resources 30:219-252. https://doi.org/10.1146/annurev.energy.30.050504.164507

Neville, B. A., S. J. Bell, and G. J. Whitwell. 2011. Stakeholder salience revisited: refining, redefining, and refueling an underdeveloped conceptual tool. Journal of Business Ethics 102 (3):357-378. https://doi.org/10.1007/s10551-011-0818-9

O'Farrell, P. J., B. Reyers, D. C. Le Maitre, S. J. Milton, B. Egoh, A. Maherry, C. Colvin, D. Atkinson, W. De Lange, J. N. Blignaut, and R. M. Cowling. 2010. Multi-functional landscapes in semi arid environments: implications for biodiversity and ecosystem services. Landscape Ecology 25(8):1231-1246. https://doi. org/10.1007/s10980-010-9495-9

Palomo, I., B. Martín-López, M. Potschin, R. Haines-Young, and C. Montes. 2013. National parks, buffer zones and surrounding 
lands: mapping ecosystem service flows. Ecosystem Services 4:104-116. https://doi.org/10.1016/j.ecoser.2012.09.001

Palomo, I., C. Montes, B. Martín-López, J. A. González, M. García-Llorente, P. Alcorlo, and M. R. García Mora. 2014. Incorporating the social-ecological approach in protected areas in the Anthropocene. BioScience 64(3):181-191. http://dx.doi. org/10.1093/biosci/bit033

Perrotton, A., M. de Garine-Wichatitsky, H. Valls-Fox, and C. Le Page. 2017. My cattle and your park: codesigning a role-playing game with rural communities to promote multistakeholder dialogue at the edge of protected areas. Ecology and Society 22 (1):35. https://doi.org/10.5751/ES-08962-220135

Pimm, S. L., M. Ayres, A. Balmford, G. Branch, K. Brandon, T. Brooks, R. Bustamante, R. Costanza, R. Cowling, L. M. Curran, A. Dobson, S. Farber, G. A. B. da Fonseca, C. Gascon, R. Kitching, J. McNeely, T. Lovejoy, R. A. Mittermeier, N. Myers, J. A. Patz, B. Raffle, D. Rapport, P. Raven, C. Roberts, J. P. Rodriguez, A. B. Rylands, C. Tucker, C. Safina, C. Samper, M. L. J. Stiassny, J. Supriatna, D. H. Wall, and D. Wilcove. 2001. Can we defy nature's end? Science 293(5538):2207-2208. https://doi. org/10.1126/science.1061626

Prell, C., K. Hubacek, M. Reed, C. Quinn, N. Jin, J. Holden, T. Burt, M. Kirby, and J. Sendzimir. 2007. If you have a hammer everything looks like a nail: traditional versus participatory model building. Interdisciplinary Science Reviews 32(3):263-282. https:// doi.org/10.1179/030801807X211720

Rastogi, A., R. Badola, S. Ainul Hussain, and G. M. Hickey. 2010. Assessing the utility of stakeholder analysis to protected areas management: the case of Corbett National Park, India. Biological Conservation 143(12):2956-2964. https://doi.org/10.1016/j. biocon.2010.04.039

Rastogi, A., S. Thapliyal, and G. M. Hickey. 2014. Community action and tiger conservation: assessing the role of social capital. Society and Natural Resources 27(12):1271-1287. https://doi. org/10.1080/08941920.2014.917753

Reed, M. S. 2008. Stakeholder participation for environmental management: a literature review. Biological Conservation 141 (10):2417-2431. https://doi.org/10.1016/j.biocon.2008.07.014

Reed, M. S., A. Graves, N. Dandy, H. Posthumus, K. Hubacek, J. Morris. C. Prell, C. H. Quinn, and L. C. Stringer. 2009. Who's in and why? A typology of stakeholder analysis methods for natural resource management. Journal of Environmental Management 90(5):1933-1949. https://doi.org/10.1016/j. jenvman.2009.01.001

Roe, D., F. Nelson, and C. Sandbrook. 2009. Community management of natural resources in Africa: impacts, experiences and future directions. Natural Resource Issues No. 18. International Institute for Environment and Development (IIED), London, UK.

Schmeer, K. 1999. Guidelines for conducting a stakeholder analysis. A Partnership for Health Reform Publication. Abt Associates, Bethesda, Maryland, USA.

Schwabe, F., T. Göttert, N. Starik, S. R. Levick, and U. Zeller. 2015. A study on the postrelease behaviour and habitat preferences of black rhinos (Diceros bicornis) reintroduced into a fenced reserve in Namibia. African Journal of Ecology 53 (4):531-539. https://doi.org/10.1111/aje.12245

Scoones, I., A. Bishi, N. Mapitse, R. Moerane, M. L. Penrith, R. Sibanda, G. R. Thomson, and W. Wolmer. 2010. Foot-and-mouth disease and market access: challenges for the beef industry in southern Africa. Pastoralism 1:135-164.

Shackleton, C. M., and S. E. Shackleton. 2004. The importance of non-timber forest products in rural livelihood security and as safety nets: a review of evidence from South Africa. South African Journal of Science 100(11-12):658-664.

Siamudaala, V. M., V. R. Nyirenda, and L. M. Saiwana. 2009. Effectiveness of law enforcement on wildlife crimes in the Kafue ecosystem in Zambia. ZAWA. New Horizon Printing Press, Chilanga, Zambia.

Stoll-Kleemann, S. 2001a. Barriers to nature conservation in Germany: a model explaining opposition to protected areas. Journal of Environmental Psychology 21(4):369-385. https://doi. org/10.1006/jevp.2001.0228

Stoll-Kleemann, S. 2001b. Opposition to the designation of protected areas in Germany. Journal of Environmental Planning and Management 44(1):109-128. https://doi.org/10.1080/09640560123606

Suŝkevičs, M., K. Tillemann, and M. Külvik. 2013. Assessing the relevance of stakeholder analysis for national ecological network governance: the case of the Green Network in Estonia. Journal for Nature Conservation 21(4):206-213. https://doi.org/10.1016/j. jnc.2012.12.007

Treves, A., R. B. Wallace, and S. White. 2009. Participatory planning of interventions to mitigate human-wildlife conflicts. Conservation Biology 23(6):1577-1587. https://doi.org/10.1111/ j.1523-1739.2009.01242.x

Trinkel, M., P. H. Fleischmann, and R. Slotow. 2017. Electrifying the fence or living with consequences? Problem animal control threatens the long-term viability of a free-ranging lion population. Journal of Zoology 301(1):41-50. https://doi. org/10.1111/jzo.12387

Van Assche, K., R. Beunen, J. Jacobs, and P. Teampau. 2011. Crossing trails in the marshes: rigidity and flexibility in the governance of the Danube Delta. Journal of Environmental Planning and Management 54(8):997-1018. https://doi. org/10.1080/09640568.2010.547687

Varvasovszky, Z., and R. Brugha. 2000. How to do (or not to do) a stakeholder analysis. Health Policy and Planning 15(3):338-345. http://dx.doi.org/10.1093/heapol/15.3.338

Watson, J. E. M., N. Dudley, D. B. Segan, and M. Hockings. 2014. The performance and potential of protected areas. Nature 515:67-73. https://doi.org/10.1038/nature13947

Weaver, L. C., and T. Peterson. 2008. Namibia communal area conservancies. Best Practices in Sustainable Hunting 2008:48-52.

Weaver, L. C., and P. Skyer. 2003. Conservancies: integrating wildlife land-use options into the livelihood, development and conservation strategies of Namibian communities. Paper presented at the Vth World Parks Congress of IUCN to the Animal 
Health and Development (AHEAD) Forum, Durban, South Africa, September 8-17.

Wells, M. P., and T. O. McShane. 2004. Integrating protected area management with local needs and aspirations. Ambio 33 (8):513-519. http://dx.doi.org/10.1579/0044-7447-33.8.513

Zeller, U., N. Starik, and T. Göttert. 2017. Biodiversity, land use and ecosystem services - an organismic and comparative approach to different geographical regions. Global Ecology and Conservation 10(C):114-125. https://doi.org/10.1016/j.gecco.2017.03.001 


\section{Appendix 1}

\section{Study sample of individuals interviewed and the sample selection techniques used}

\begin{tabular}{|c|c|c|}
\hline Stakeholder category & $\begin{array}{l}\text { Number of } \\
\text { people/households } \\
\text { interviewed }\end{array}$ & Sample selection \\
\hline Conservancies: & & $\begin{array}{l}\text { Systematic sampling } \\
\text { strategy }^{1}\end{array}$ \\
\hline \#Khoadi-//Hoas & 12 & \\
\hline Ehi-Rovipuka & 12 & \\
\hline Private properties: & & $\begin{array}{l}\text { All properties in study } \\
\text { area }\end{array}$ \\
\hline Livestock producers & 6 & \\
\hline Tourism/hunting facilities & 6 & \\
\hline $\begin{array}{l}\text { Combination farmers } \\
\text { (livestock production and hunting } \\
\text { and/or tourism) }\end{array}$ & 8 & \\
\hline Resettlement farm: & & $\begin{array}{l}\text { Systematic sampling } \\
\text { strategy }^{\neq}\end{array}$ \\
\hline Seringkop & 12 & \\
\hline Other: & & Snowball technique $e^{\S}$ \\
\hline Etosha National Park Management & 5 & \\
\hline State Veterinary Department & 4 & \\
\hline Experts & 2 & \\
\hline NGO representatives & 6 & \\
\hline Media & 2 & \\
\hline Consumers (hunters/tourists) & 4 & \\
\hline Investor & 1 & \\
\hline Union representatives & 2 & \\
\hline
\end{tabular}

${ }^{\dagger}$ (Technique as adapted from Newing et al. 2011).

This entailed obtaining a list of registered communal conservancy members from each conservancy's management committee. Each list was alphabetized and considered as the sampling frame. Microsoft Excel 7.0 was used to select every $20^{\text {th }}$ name on the list with equal selection probability. When the selected person was not available for the interview, or did not wish to comply, then a list of alternative selections was consulted and interviewed instead. For $\neq$ Khoadi-//Hoas, only members residing in the main settlement, Marienhöhe, were included.

${ }^{\ddagger} \mathrm{A}$ list of registered farmers was acquired from the Traditional Authority and the same systematic sampling strategy as above was carried out.

${ }^{\S}$ This involved consulting each stakeholder, identified by experts with prior experience in the area, and requesting them to list other potential stakeholders until no new stakeholders or stakeholder groups could be identified (Billgren and Holmén 2008, Newing et al. 2011). 


\section{Appendix 2}

\section{Stakeholder identification and classification}

To identify stakeholders, we considered the following criteria, as described by BorriniFeyerabend (1996). Firstly, stakeholders are aware of their role or stake in the system under study. Secondly, they possess certain capacities, such as knowledge or skills, and relevance to the system and its resources (e.g. their proximity to the protected area or rights over land and natural resources). Lastly, stakeholders are able to influence decision-making and bear the costs of doing so, or are willing to mobilize resources, including their time, money and political weight to influence the decision-making process.

Since it is not possible to include all stakeholders, demarcations, based on well-substantiated criteria, are needed (Clarke and Clegg 1998). In this case, geographical criteria such as the western and southern boundary of the ENP are used, since this is where the expansion of the protected area system takes place (Brown et al. 2005). Furthermore, according to Achterkamp and Vos (2008), to facilitate stakeholder identification, a stakeholder definition, based on a stakeholder classification model, is required. Freeman's (2010: 46) 'affect criterion' is the most commonly used and distinguishes between affected stakeholders and stakeholders who can affect the outcome of a policy or project.

Most stakeholder analyses implicitly assume that stakeholder desires are similar or identical to outcomes as expressed by the investigators or analysts. Hence, we included a consideration of a stakeholder's interest in the system under study and the suggested expansion thereof.

Once codes and categories were derived using QSR-NVivo (version 10), stakeholders were categorized. According to similarities and differences in roles, categories were developed from codes, giving inference to a stakeholder's stakes. (For example, participants citing their role in the study system as livestock farmers were grouped together and their stakes assumed to be similar). Stakeholders and their roles or stakes were thus also classified according to the 'affect criterion' (Freeman 1984, 2010), to classify 'active' and 'passive' stakeholders, i.e. those who affect (determine) a decision or action and those affected by the decision. Primary stakeholders refer to individuals or groups with a higher level of interdependence between themselves and the protected area system. Secondary stakeholders are those who may influence or affect decisions regarding the protected area landscape, or who are themselves influenced or affected by these decisions, but who are not engaged or essential to the decision-making process. 
Finally, stakeholders were further classified according to attributes of position, interest and power. Position gives an indication of stakeholder support for, or opposition to, an expanded protected area network around the ENP. Interests refer to the advantages and disadvantages, as perceived by stakeholders, of being part of this network. While power is indicative of the resources a stakeholder claims they are able to mobilize to express their position (i.e. support or opposition toward the issue). 
Appendix 3

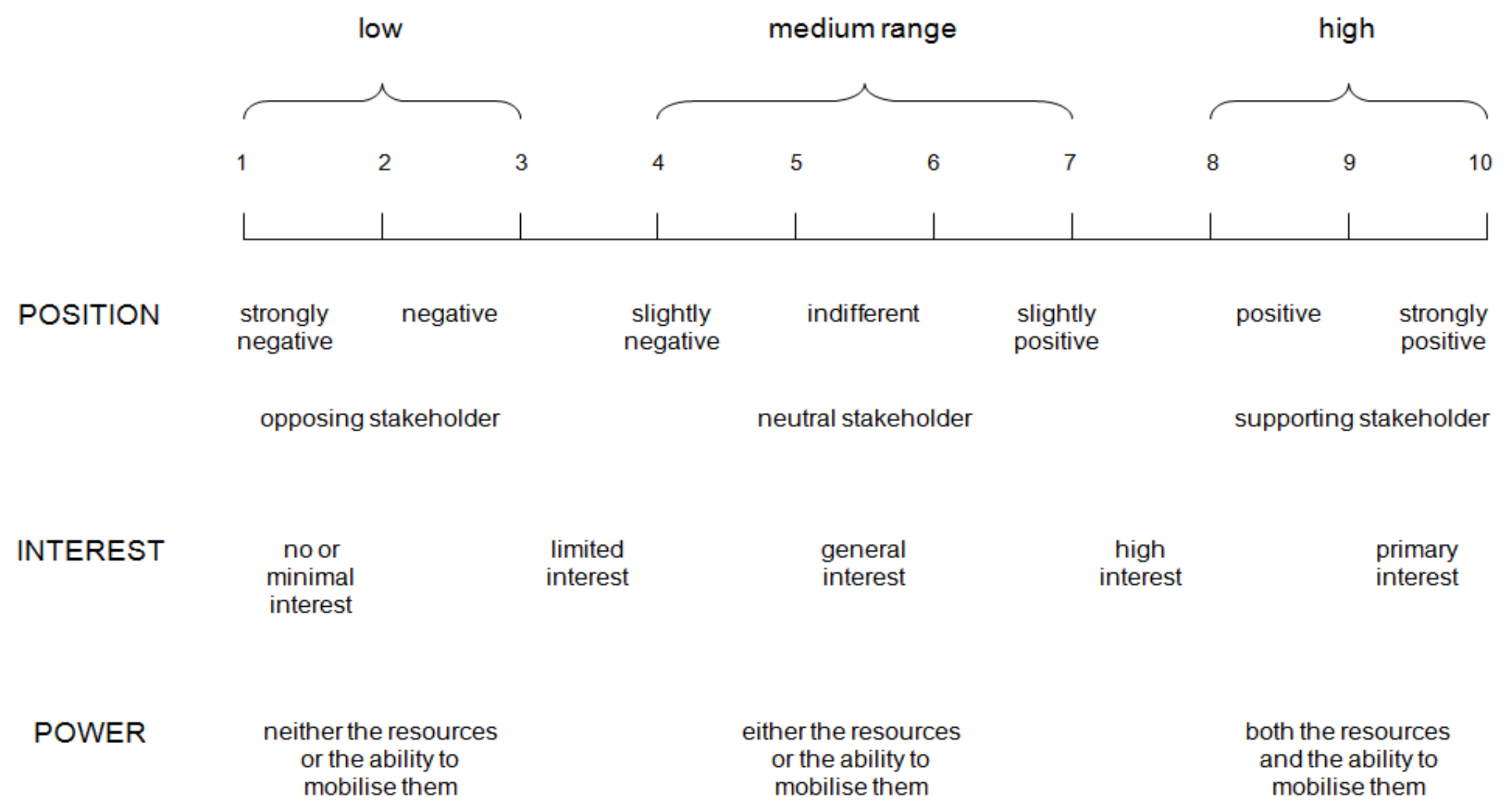

The 10-point scale used to score stakeholder attributes 
The dimensions of stakeholder characteristics analyzed are position, interests, and power. We used 10 points $(1-10)$ to allow for more comparisons of the system under study and to create a wider distribution since the extremes are often avoided in scales with smaller numbers (Oppenheim 2003). Semantic differentials indicated the cognitive meaning of concepts along the scale (e.g. a stakeholder is strongly negative or opposes the expansion of the protected area due to the potential of more predators in the general vicinity and the perceived increase in human-wildlife conflict). As opposed to using linguistically anchored, Likert-type scales where perceptual judgements about the urgency or importance of the concept is classified as 'very important' to 'not important' (Osgood et al. 1957). The latter are based on perceptual judgments and classifications such as 'very important', which must be clearly defined and reduces the potential of comparisons across stakeholder groups of different sizes and functions. (For example, the way in which individuals valued costs and benefits to being adjacent to the national park, which represents interest, had a strong cultural and socio-economic component. This potentially influences their perceptions of being part of the social-ecological system and how they may be affected by changes). The 10-point scales therefore allow for potential comparisons and by having more points, it increases discrimination and creates a wider distribution since assessors often avoid the extremes in scales with smaller numbers (Oppenheim 2003). As pointed out by Heidrich et al. (2009) using 10-point scales creates a fuzzy set for each individual or group evaluated. Across the dimensions of position, interest and power, scores of 4-7 inclusive, are considered as the middle range and those falling outwith could be viewed as particularly high or low/negative or positive. 


\section{Appendix 4}

\section{Summary of interview questions}

\begin{tabular}{ll}
\hline \hline Attribute & Question \\
\hline Position & What is your role in the system surrounding you (i.e. in the social ecological \\
system)? & What is your capacity (owner, co-owner, manager, resident)? \\
& Would you ever consider changing the focus of land management? \\
& Would you ever consider diversifying your focus? \\
& Would you say you oppose or support the concept of an expanded protected \\
area around Etosha National Park (ENP)? & How would an expanded protected area network around ENP affect you? \\
Interests & How would you affect an expanded protected area network around ENP? \\
& What do you consider to be the most important advantage to farming on the \\
borders of ENP? & What do you consider to be the most important disadvantage to farming on \\
the borders of ENP? \\
What are the relationships between you and other resource users/land \\
managers?
\end{tabular}




\section{Appendix 5}

\section{Assessment of stakeholder attributes namely cumulative values of position, interest and power of stakeholder groups}

\begin{tabular}{|c|c|c|c|c|c|c|c|c|c|c|c|c|c|c|c|}
\hline \multirow[t]{3}{*}{$\begin{array}{l}\text { Stakeholder } \\
\text { group }\end{array}$} & \multicolumn{5}{|c|}{ Position } & \multicolumn{5}{|c|}{ Interest } & \multicolumn{5}{|c|}{ Power } \\
\hline & \multicolumn{3}{|c|}{$\begin{array}{l}\text { (\% interviewees of } \\
\text { total in the } \\
\text { stakeholder group) }\end{array}$} & \multirow[t]{2}{*}{$\begin{array}{c}\text { cumulative } \\
\text { value } \\
\left(1^{*}(A)+2^{*}(B)+\right. \\
3(C)) / 3\end{array}$} & \multirow[t]{2}{*}{$\begin{array}{l}\text { position } \\
\text { level }^{\dagger}\end{array}$} & \multicolumn{3}{|c|}{$\begin{array}{l}\text { (\% interviewees of total } \\
\text { in the stakeholder } \\
\text { group) }\end{array}$} & \multirow[t]{2}{*}{$\begin{array}{c}\text { cumulative } \\
\text { value } \\
\left(1^{\star}(D)+2^{*}(E)+\right. \\
3(F)) / 3\end{array}$} & \multirow[t]{2}{*}{$\begin{array}{l}\text { interest } \\
\text { level }^{\dagger}\end{array}$} & \multicolumn{3}{|c|}{$\begin{array}{l}\text { (\% interviewees of total in } \\
\text { the stakeholder group) }\end{array}$} & \multirow[t]{2}{*}{ 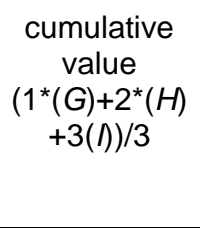 } & \multirow[t]{2}{*}{$\begin{array}{l}\text { power } \\
\text { level }^{\dagger}\end{array}$} \\
\hline & $\begin{array}{l}\text { Low } \\
A(\%)\end{array}$ & $\begin{array}{l}\text { Med } \\
B(\%) \\
\end{array}$ & $\begin{array}{l}\text { High } \\
C(\%)\end{array}$ & & & $\begin{array}{l}\text { Low } \\
D(\%) \\
\end{array}$ & $\begin{array}{l}\text { Med } \\
E(\%) \\
\end{array}$ & $\begin{array}{l}\text { High } \\
F(\%) \\
\end{array}$ & & & $\begin{array}{l}\text { Low } \\
G(\%)\end{array}$ & $\begin{array}{l}\text { Med } \\
H(\%)\end{array}$ & $\begin{array}{l}\text { High } \\
I(\%)\end{array}$ & & \\
\hline \multirow{5}{*}{$\begin{array}{l}\text { Livestock farmers } \\
(n=8) \\
\text { Tourism facilities } \\
(n=16) \\
\text { Conservancy } \\
\text { members }(n=12) \\
\text { Resettlement } \\
\text { farmers }(n=12) \\
\text { ENP } \\
\text { Management } \\
(n=5) \\
\text { Government } \\
(n=4)\end{array}$} & 25 & 62.5 & 12.5 & 62.5 & $\bmod$ & 0 & 50 & 50 & 83.3 & high & 0 & 12.5 & 87.5 & 95.8 & high \\
\hline & 25 & 75 & 0 & 58.3 & $\bmod$ & 0 & 100 & 0 & 66.7 & mod & 0 & 100 & 0 & 66.7 & $\bmod$ \\
\hline & 27.3 & 72.7 & 0 & 57.6 & $\bmod$ & 81.8 & 18.2 & 0 & 39.4 & low & 81.8 & 18.2 & 0 & 39.4 & low \\
\hline & 0 & 20 & 80 & 93.3 & high & 0 & 40 & 60 & 86.7 & high & 20 & 80 & 0 & 60 & $\bmod$ \\
\hline & 25 & 25 & 50 & 75 & $\bmod$ & 0 & 75 & 25 & 75 & $\bmod$ & 0 & 50 & 50 & 83.3 & high \\
\hline Experts $(n=2)$ & 100 & 0 & 0 & 33.3 & low & 0 & 0 & 100 & 100 & high & 0 & 100 & 0 & 66.7 & $\bmod$ \\
\hline Consumers $(n=4)$ & 0 & 75 & 25 & 75 & $\bmod$ & 25 & 50 & 25 & 66.7 & mod & 100 & 0 & 0 & 33.3 & low \\
\hline NGOs $(n=6)$ & 16.7 & 16.7 & 66.6 & 83.3 & high & 16.7 & 50 & 33.3 & 72.2 & mod & 83.3 & 16.7 & 0 & 38.9 & low \\
\hline $\begin{array}{l}\text { Unions }(\mathrm{n}=2) \\
\text { Insurance/ }\end{array}$ & 100 & 0 & 0 & 33.3 & low & 50 & 50 & 0 & 50 & mod & 100 & 0 & 0 & 33.3 & low \\
\hline investors $(n=1)$ & 0 & 100 & 0 & 66.7 & mod & 100 & 0 & 0 & 33.3 & low & 100 & 0 & 0 & 33.3 & low \\
\hline Media $(n=2)$ & 50 & 50 & 0 & 50 & $\bmod$ & 100 & 0 & 0 & 33.3 & low & 100 & 0 & 0 & 33.3 & low \\
\hline
\end{tabular}

${ }^{\dagger} 0-45 \%$ - low; $45-75 \%$ - moderate; $75-100 \%$ - high 